\title{
Validated Analytical Modeling of Diesel Engines Intake Manifold with a Flexible Crankshaft
}

\author{
Salah A. M. Elmoselhy ${ }^{1}$ (D) Waleed F. Faris ${ }^{2, *}$ and Hesham A. Rakha ${ }^{3}$ (D) \\ 1 CFisUC, Department of Physics, University of Coimbra, P-3004 516 Coimbra, Portugal; \\ salah.elmoselhy@msm.nl \\ 2 Department of Mechanical Engineering, International Islamic University Malaysia, Gombak, \\ Kuala Lumpur 53100, Malaysia \\ 3 Virginia Tech Transportation Institute, Virginia Polytechnic Institute and State University, \\ 3500 Transportation Research Plaza, Blacksburg, VA 24061, USA; hrakha@vt.edu \\ * Correspondence: wfaris@vt.edu
}

check for updates

Citation: Elmoselhy, S.A.M.; Faris, W.F.; Rakha, H.A. Validated Analytical Modeling of Diesel Engines Intake Manifold with a Flexible Crankshaft. Energies 2021, 14, 1287. https://doi.org/10.3390/ en14051287

Academic Editors:

Constantine Rakopoulos and Ali Elkamel

Received: 17 November 2020

Accepted: 25 January 2021

Published: 26 February 2021

Publisher's Note: MDPI stays neutral with regard to jurisdictional claims in published maps and institutional affiliations.

Copyright: (C) 2021 by the authors. Licensee MDPI, Basel, Switzerland. This article is an open access article distributed under the terms and conditions of the Creative Commons Attribution (CC BY) license (https:// creativecommons.org/licenses/by/ $4.0 /)$.

\begin{abstract}
The flexibility of a crankshaft exhibits significant nonlinearities in the analysis of diesel engines performance, particularly at rotational speeds of around $2000 \mathrm{rpm}$. Given the explainable mathematical trends of the analytical model and the lack of available analytical modeling of the diesel engines intake manifold with a flexible crankshaft, the present study develops and validates such a model. In the present paper, the mass flow rate of air that goes from intake manifold into all the cylinders of the engine with a flexible crankshaft has been analytically modeled. The analytical models of the mass flow rate of air and gas speed dynamics have been validated using case studies and the ORNL and EPA Freeway standard drive cycles showing a relative error of $7.5 \%$ and $11 \%$, respectively. Such values of relative error are on average less than those of widely recognized models in this field, such as the GT-Power and the CMEM, respectively. A simplified version for control applications of the developed models has been developed based on a sensitivity analysis. It has been found that the flexibility of a crankshaft decreases the mass flow rate of air that goes into cylinders, resulting in an unfavorable higher rate of exhaust emissions like CO. It has also been found that the pressure of the gas inside the cylinder during the intake stroke has four elements: a driving element (intake manifold pressure) and draining elements (vacuum pressure and flow losses and inertial effect of rotating mass). The element of the least effect amongst these four elements is the vacuum pressure that results from the piston's inertia and acceleration. The element of the largest effect is the pressure drop that takes place in the cylinder because of the air/gas flow losses. These developed models are explainable and widely valid so that they can help in better analyzing the performance of diesel engines.
\end{abstract}

Keywords: nonlinear dynamics; fluid mechanics; diesel engine performance; exhaust emissions; modeling and simulation

\section{Article Highlights}

1. Validated Analytical model of the mass flow rate of air goes into cylinders with a flexible crankshaft;

2. Flexibility of the crankshaft decreases the mass flow rate of air that goes into cylinders, resulting in unfavorable higher rate of exhaust emission;

3. Cylinder pressure during intake stroke has four elements: a driving element (intake manifold pressure) and draining elements (vacuum pressure, flow losses and inertial effect of rotating mass).

\section{Introduction}

The continual demand for diesel powertrain development is due to the distinguished operating features the diesel powertrains exhibit [1]. As a cost-effective tool for developing 
diesel powertrains, modeling assumes a key role in such endeavor [2,3]. This is particularly true for Intelligent Transportation Systems (ITS) [4,5]. Due to its relative location, intake manifold significantly influences the performance of the rest of the elements of diesel powertrain so that its modeling comes first with respect to diesel powertrain.

The research area of mechanical energy modeling and analysis still has been a hot area of research. This is evident in very recent research papers developed at highly esteemed institutions such as [6,7]. In addition, very recently the featured paper in the "Energies" journal-Volume 14-Issue 1 in 2021, has been on diesel engines performance. This indicates that this area of research is still a hot topic that is still investigated by highly esteemed European institutions such as [8].

The intake manifold along with the crankshaft, which are interconnected through the engine cylinder assembly, significantly influence the net power of the engine. Therefore, the modeling of their interconnection becomes critical. Because the flexibility of the crankshaft is an intrinsic characteristic of the dynamics of the crankshaft, the influence of such flexibility should also be modeled.

Guzzella et al. [9] reported that there are two categories of modeling the engine dynamics: (1) Mean Value Model which spreads out major processes in the engine for modeling the input-output behavior with good accuracy but low computational cost; (2) Discrete Event Model which explicitly describes the reciprocating behavior of the engine. However, for the cylinder and intake manifold, the mean value models do not show the influence of the crank angle. In addition, Guzzella et al. did not present a discrete event model of the air mass flow rate in intake manifold and engine's cylinder as a function of crank angle analytically.

Acquati et al. [10] proposed a mean value model of the air flow and pressure in the intake manifold of spark ignition engines. However, the mean value model does not show the influence of the crank angle on the mass flow rate of air in the engine's cylinder and on the gas speed dynamics in the engine's cylinder.

Among the key models in this field is the model developed by Ouenou-Gamo et al. [11] that analytically modeled the air intake process in a turbocharger diesel engine using the camshaft angular position. That study showed the influence of the turbocharger on the manifold and on the cylinders' parameters during their filling. However, that model neglects the gases' kinetic energy and the gas flow's momentum conservation. Other researchers tried to explain the mechanism of fuel consumption that influences the actual Air/Fuel ratio based on understanding the collision behavior of fuel drops in the cylinder of diesel engines [12].

Aguilera-Gonza et al. [13], developed a pressure model based on fuzzy logic for regulating the intake manifold pressure in a four-cylinder diesel engine air-path system with Exhaust Gas Recirculation (EGR) and Variable Geometry Turbocharger (VGT). However, that model did not show analytically the influence of the intake manifold's pressure on the dynamics of the crankshaft.

Considering irreversible thermodynamic processes, Mehta and Bharti [14] presented irreversible Otto cycle model for net power generation and efficiency calculation by including bypass heat leakage, frictional losses and internal irreversibility factors associated with compression and expansion process. They showed that the power is independent of heat leakage term but is affected by irreversibility in terms of flow losses and frictional losses.

The technology of a balance shaft with eccentric weight for offsetting the vibrations of the crankshaft has been also modeled. In this line of modeling, Kumhar et al. [15] have identified the two sources of diesel engine's vibrations: (i) vibrations because of rotating and reciprocating inertial forces that act on the crankshaft and the parts connecting with it, (ii) Torsional vibration of the crankshaft due to combustion pulses. Kumhar et al., proposed a computational model of a balancer shaft with eccentric masses to counter balance these two vibrational forces. However, they have not shown analytically the influence of the intake manifold's pressure on the dynamics of the crankshaft. 
Chaubey and Tiwari [16] also developed a computational model but of the intake manifold of a four-cylinder engine. They showed the effects of shape of runners on the intake manifold's output. However, that research did not analytically model the mass flow rate of air in the engine's cylinder nor did it analytically model the gas dynamics in the engine's cylinder.

Vojtíšek and Kotek [17] compared real driving measurement of air flow in gasoline engines as well as in diesel engines with a generic analytical model of the mass flow rate based on volumetric efficiency and throttling. They reported that the relative error of such a model exceeds $10 \%$. However, the paper did not take into account the effect of the flexibility of the crankshaft on the mass flow rate of air in the engine's cylinder.

Rakha et al. [18] indicated that a widely valid and microscopic model of diesel engines is yet sought for evaluating the diesel powertrain technologies. Faris et al. [19] therefore modeled analytically the intake manifold of supercharged diesel engines treating the crankshaft of the engine as an inflexible shaft. However, the flexibility of the crankshaft was not taken into consideration in that modeling.

Albeit vehicle analytical modeling describes the physical phenomena associated with engines with explainable mathematical trends, no analytical model has been developed as yet of the supercharged diesel intake manifold taking into account the flexibility of the crankshaft. The significance of this research is indicated in light of recent research that reflects the importance of the line of research of the effect of gas pressure on diesel engines performance to the research community [20]. The significance of the flexibility of the crankshaft captured the attention of several researchers, such as Ma et al. [21], but they opted for computational modeling of the crankshaft based on finite element analysis. The flexibility of the crankshaft in diesel engines exhibits significant nonlinearities. Particularly, at crankshaft rotational speeds of around $2000 \mathrm{rpm}$ or higher, which is the near optimal rotational speed for near optimal mechanical efficiency, the influence of such flexibility on diesel engines performance becomes considerable.

\section{Materials and Methods}

The present research is quantitative and is based on a theoretical approach. This research employs exploratory and descriptive techniques. Analytical modeling and simulation are employed in this research. A sensitivity analysis is conducted for simplifying the developed models. Field data of two case studies gathered from literature and the ORNL and EPA Freeway standard drive cycles are used for experimental validation. The experimental data gathered from these two case studies are used as a benchmark for validating the results of the analytical models presented in this paper. For checking the consistency of the developed analytical model with the experimental and field data, the range of the crankshaft rotational angle $(\theta)$ is equally and symmetrically divided into a few segments [22]. The developed model is thus tested at several values of $\theta$.

The research assumptions in this paper include: (i) Because there is no change in phase in the air flow throughout the compressor and the minimum temperature of the air flow throughout the compressor is far above the critical point of atmospheric air, air is considered an ideal gas; (ii) Because air is considered non viscous fluid, the flow in the intake manifold is non viscous so that the gas flow is considered one-dimensional flow; (iii) The difference in pressure head in the air/gas flow due to elevation in the engine is neglected.

\section{Research Idea and Its Novelty}

The key idea of this study is to develop and validate an analytical model of supercharged diesel intake manifolds taking the flexibility of the crankshaft of engines into account. The present research analytically models: (a) the rate of mass flow of air that goes into cylinders with a flexible crankshaft, (b) The intake manifold gas speed dynamics.

The following contributions are accomplished in the present study: 
1. Analytically modeling the mass flow rate of air goes into cylinders with a flexible crankshaft (Section 4);

2. A simplified version for control applications of the developed models of both the mass flow rate of the air that goes from intake manifold into all the cylinders of the engine and the gas speed dynamics has been developed based on a sensitivity analysis (Section 5);

3. Validating these developed analytical models using case studies and analyzing the simulated results statistically (Section 6);

4. The simulation and statistical analysis presented in Section 6 reveal that the relative errors are of $7.5 \%$ and $11 \%$ which are on average less than that of well-known models such as the GT-Power and CMEM, respectively;

5. It has been found that the flexibility of the crankshaft decreases the mass flow rate of air that goes into cylinders, resulting in unfavorable higher rate of exhaust emissions such as $\mathrm{CO}$;

6. It has been also found that the pressure of the gas inside the cylinder during the intake stroke has four elements: a driving element (intake manifold pressure), and draining elements (vacuum pressure and flow losses and inertial effect of rotating mass).

The developed models are simplified in order to suit control applications of supercharged diesel engines. The developed models are widely valid with explainable mathematical trends so that their developed simplified version can help in better analysing and optimizing the performance of diesel engines.

\section{Analytical Modeling of the Mass Flow Rate of Air that Goes into Cylinders with a Flexible Crankshaft}

The flexibility of the crankshaft of the engine is illustrated in Figure 1. In Figure 1a, the flexibility of the crankshaft is reflected in a deflection in the crankshaft as indicated by the crank-webs. Figure $1 \mathrm{~b}$ shows the stressed crank of the crankshaft before and after such a deflection.

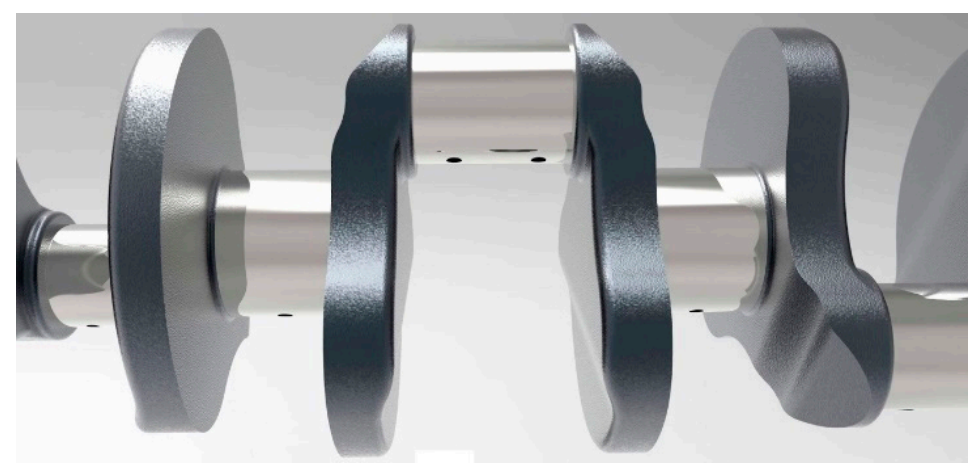

(a)

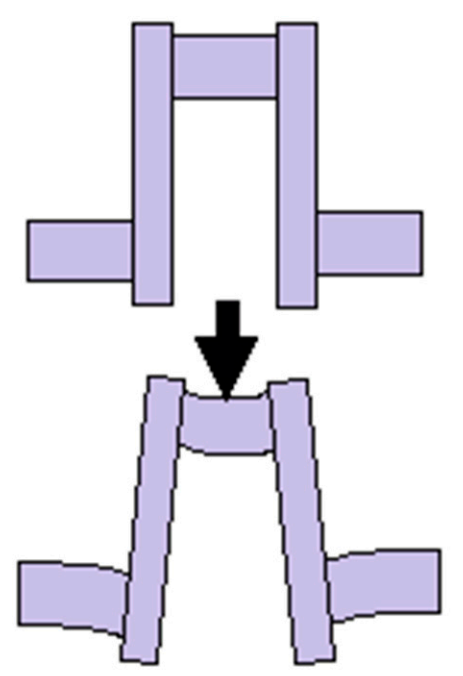

(b)

Figure 1. (a) Deflected crankshaft as indicated by the crank-webs, (b) crankshaft pin before and after deflection due to pressure.

The present research analyses the intake manifold of four-cylinder supercharged diesel engines equipped with an Electronic Throttle Control (ETC). This set-up configuration is illustrated in Figure 2. Figure 2 depicts an idealized abstraction/pictorial model of the real supercharged diesel engine in an endeavour to analyze the real diesel engine, which is a widely accepted approach [23]. 


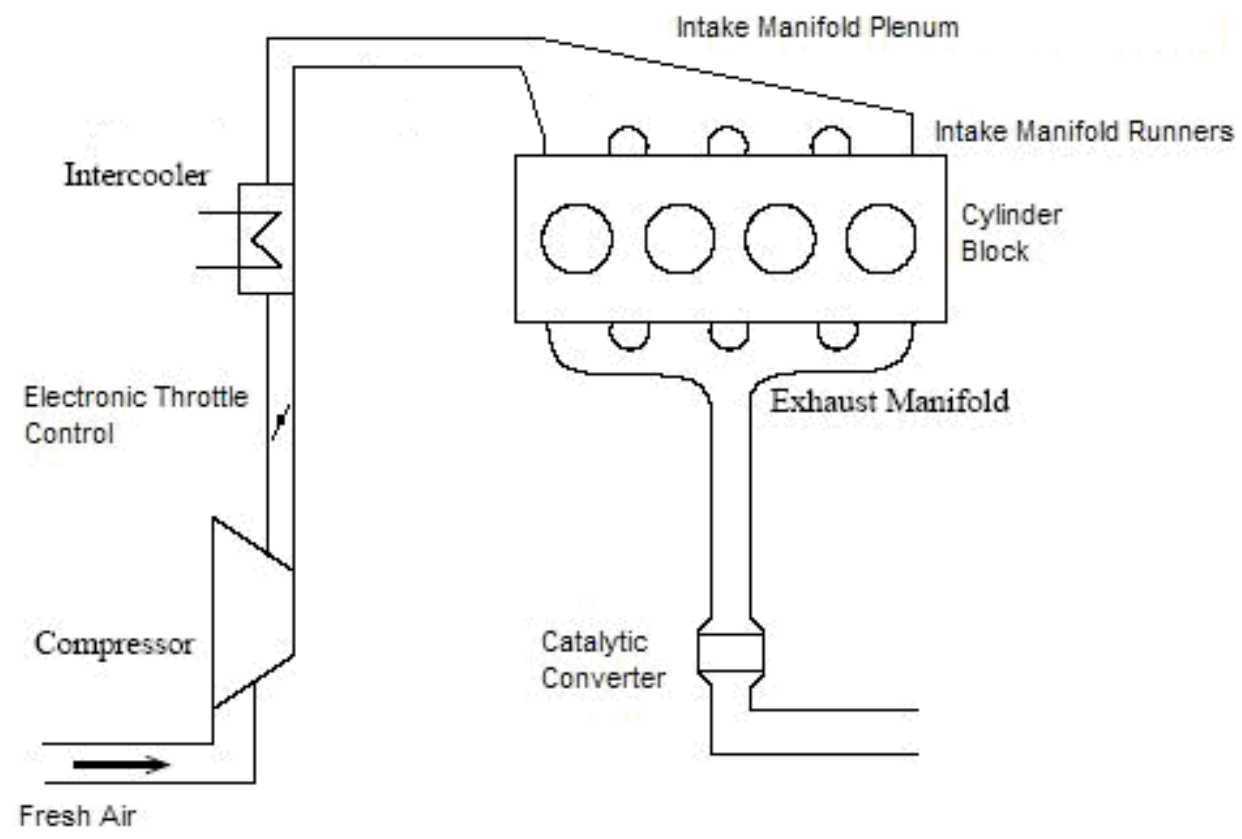

Figure 2. Intake manifold of a four-cylinder supercharged diesel engine $[19,23]$.

In order to evaluate the mass flow rate of the air that goes from intake manifold to all the cylinders of the engine, $\dot{m}_{A C}$, taking into account the flexibility of the crankshaft let us evaluate the cylinder pressure, $P_{C y l}$, taking into account the flexibility of the crankshaft. Because pressure drop occurs instantaneously, $P_{C y l}$ during the exhaust stroke becomes equalling to the ambient pressure, $P_{\text {Atm }}[24,25]$. During the intake stroke, the pressure of the gas inside the cylinder during the intake stroke, $P_{C I}$, becomes equalling to the intake manifold pressure, $P_{i}$. However, the pressure in the cylinder drops during the intake stroke [26]. Thus, because of the effect of accelerating the reciprocating piston, a slight pressure drop takes place in the cylinder because of the generated vacuum pressure that results from the piston's inertia and acceleration, $P_{V a c}$, representing the inertial effect of the reciprocating mass [27]. In addition, further slight pressure drop takes place in the cylinder due to the air/gas flow losses, $P_{\text {Flow }}$ [28]. Moreover, the pressure influence due to the inertial effect of the rotating mass, $P_{\text {Rot }}$, further affects the in-cylinder pressure [29]. It is noteworthy in the intake stroke regarding the $P_{\text {Rot }}$ that in the range of the crankshaft rotational angle of $360^{\circ}$ to $450^{\circ}$ the $P_{\text {Rot }}$ boosts the effect of $P_{i}$, as would be indicated in the experimental validation "Section 6". However, in the range of the crankshaft rotational angle of $451^{\circ}$ to $495^{\circ}$ the $P_{\text {Rot }}$ due to the centrifugal effect of the rotating mass counteracts the effect of $P_{i}$, as would be indicated in the experimental validation "Section 6". Thus, given the variation of the sign of the $P_{\text {Rot }}$ with the crankshaft rotational angle, in the analytical modelling of the effect of $P_{\text {Rot }}$ on $P_{C y l}$, the absolute value of $P_{\text {Rot }}$ is used. Therefore, the pressure of the gas inside the cylinder during the intake stroke, $P_{C I}$, can be evaluated as follows:

$$
P_{C I}=P_{i}+P_{V a c}+\left|P_{\text {Rot }}\right|-P_{\text {Flow }}
$$

Near the end of the intake stroke, pressure equalizes throughout the runners of the intake manifold so that $P_{C y l}$ becomes equal to $P_{i}$. Hence, the in-cylinder pressure, $P_{C y l}$, can be formulated as follows:

$$
P_{C y l}=\left[\begin{array}{cc}
P_{C I} & \theta_{I V O} \leq \theta<\theta_{I V C} \\
P_{i} & \theta=\theta_{I V C}
\end{array}\right.
$$


The $P_{V a c}$ in the diesel engine cylinder can be formulated based on the definition of pressure:

$$
P_{V a c}=\frac{F_{a}}{\frac{\pi}{4} B^{2}}
$$

where:

$F_{a}$ is the force generated because of the piston's acceleration.

$B$ is Cylinder (Bore) diameter.

The $F_{a}$ indicated in Equation (3) can be evaluated following from the definition of force:

$$
F_{a}=\left(m_{P}+m_{C}\right) * a_{P}
$$

where:

$m_{P}$ is the Piston's mass.

$m_{C}$ is the mass of the gas in the clearance volume of the engine cylinder that is equal to the total mass of the gas in the engine cylinder before compression based on the principle of conservation of mass.

$a_{P}$ is the piston's instantaneous acceleration.

However, due to the fact that the $m_{P}$ is much greater than the $m_{C}$ with several orders of magnitude, the influence of the $m_{C}$ on the $F_{a}$ in Equation (4), is negligible. The flexibility of the crankshaft is represented in the distance " $d$ " indicated in Figure 3. In an endeavour to evaluate $a_{P}$ indicated in Equation (4), it follows from the definitions of displacement of the piston, $S_{d}$, instantaneous linear velocity of the piston, $S_{P}$, and acceleration of the piston, $a_{P}$, indicated in Figure 3 that

$$
S_{d}=a * \cos \theta+\sqrt{l^{2}-d^{2}-2 d * a * \sin \theta-a^{2} * \sin ^{2} \theta}
$$

where:

$a$ is the crank length.

$\theta$ is the crankshaft rotational angle.

$l$ is the length of connecting rod.

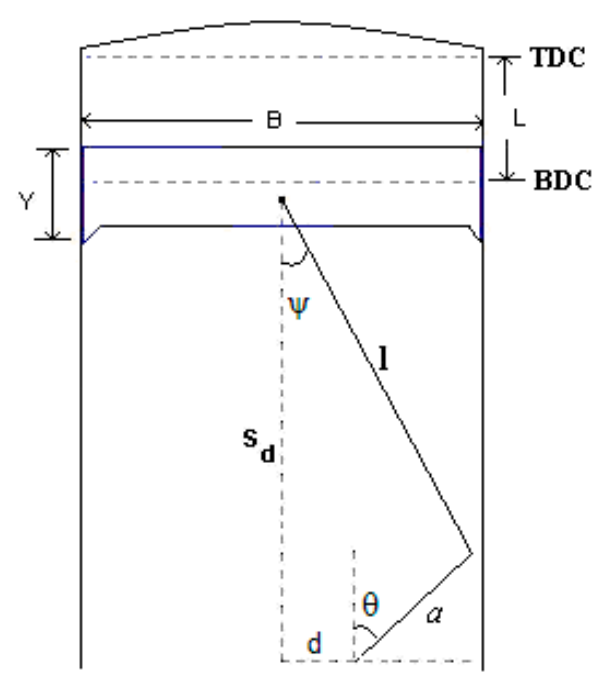

Figure 3. Abstract geometrical illustration of the cylinder, piston, connecting rod and flexible crankshaft. 
The instantaneous linear velocity of the piston, $S_{P}$, can be thus formulated by differentiation using Equation (5):

$$
S_{P}=-a *\left(\sin \theta+\frac{d * a * \cos \theta+a * \sin \theta * \cos \theta}{\sqrt{l^{2}-d^{2}-2 d * a * \sin \theta-a^{2} * \sin ^{2} \theta}}\right) \frac{d \theta}{d t}
$$

However, the crankshaft rotational speed in radian per second, $w$, in terms of the crankshaft rotational speed in rpm, $N_{m}$, can be formulated as:

$$
w=2 \pi *\left(\frac{N_{m}}{60}\right)
$$

Hence, combining Equations (6) and (7) leads to:

$$
S_{P}=-\frac{2 a \pi * N_{m}}{60} *\left(\sin \theta+\frac{d * a * \cos \theta+a * \sin \theta * \cos \theta}{\sqrt{l^{2}-d^{2}-2 d * a * \sin \theta-a^{2} * \sin ^{2} \theta}}\right)
$$

The acceleration of the piston, $a_{P}$, can be therefore formulated by differentiation following from Equation (8):

$$
a_{P}=-\frac{2 a * \pi * N_{m}}{60} *\left(\begin{array}{c}
\cos \theta-\frac{(d * a * \cos \theta+a * \sin \theta * \cos \theta)\left(-2 d * a * \cos \theta-2 a^{2} * \sin \theta * \cos \theta\right)}{2\left(l^{2}-d^{2}-2 d * a * \sin \theta-a^{2} * \sin ^{2} \theta\right)^{\frac{3}{2}}} \\
+\frac{-d * \sin \theta-a * \sin ^{2} \theta+a * \cos ^{2} \theta}{\left(l^{2}-d^{2}-2 d * a * \sin \theta-a^{2} * \sin ^{2} \theta\right)^{\frac{1}{2}}}
\end{array}\right) \frac{d \theta}{d t}
$$

By combining Equations (7) and (9):

$$
a_{P}=-\frac{a * \pi^{2} * N_{m}^{2}}{900} *\left(\begin{array}{c}
\cos \theta \\
-\frac{(d * a * \cos \theta+a * \sin \theta * \cos \theta)\left(-2 d * a * \cos \theta-2 a^{2} * \sin \theta * \cos \theta\right)}{2\left(l^{2}-d^{2}-2 d * a * \sin \theta-a^{2} * \sin ^{2} \theta\right)^{\frac{3}{2}}} \\
+\frac{-d * \sin \theta-a * \sin ^{2} \theta+a * \cos ^{2} \theta}{\left(l^{2}-d^{2}-2 d * a * \sin \theta-a^{2} * \sin ^{2} \theta\right)^{\frac{1}{2}}}
\end{array}\right)
$$

The mass of the piston, $m_{P}$, can be formulated following from the definition of mass as:

$$
m_{P}=\rho_{P} * V_{P}
$$

where:

$\rho_{P}$ is the piston' s material density, which is usually aluminium alloy.

$V_{P}$ is the volume of the piston.

Therefore, the force generated due to the piston's acceleration, $F_{a}$, can be evaluated by combining Equations (4), (10), and (11):

$$
F_{a}=\frac{\rho_{P} * \pi^{3} * B^{2} * Y * a * N_{m}^{2}}{3600} *\left(\begin{array}{c}
\cos \theta \\
-\frac{(d * a * \cos \theta+a * \sin \theta * \cos \theta)\left(-2 d * a * \cos \theta-2 a^{2} * \sin \theta * \cos \theta\right)}{2\left(l^{2}-d^{2}-2 d * a * \sin \theta-a^{2} * \sin ^{2} \theta\right)^{\frac{3}{2}}} \\
+\frac{-d * \sin \theta-a * \sin { }^{2} \theta+a * \cos ^{2} \theta}{\left(l^{2}-d^{2}-2 d * a * \sin \theta-a^{2} * \sin ^{2} \theta\right)^{\frac{1}{2}}}
\end{array}\right)
$$

where:

$Y$ is the piston's characteristic height.

Substituting Equation (12) in Equation (3):

$$
P_{\text {Vac }}=\frac{\rho_{P} * \pi^{2} * Y * a * N_{m}^{2}}{900} *\left(\begin{array}{c}
\cos \theta \\
-\frac{(d * a * \cos \theta+a * \sin \theta * \cos \theta)\left(-2 d * a * \cos \theta-2 a^{2} * \sin \theta * \cos \theta\right)}{2\left(l^{2}-d^{2}-2 d * a * \sin \theta-a^{2} * \sin ^{2} \theta\right)^{\frac{3}{2}}} \\
+\frac{-d * \sin \theta-a * \sin { }^{2} \theta+a * \cos ^{2} \theta}{\left(l^{2}-d^{2}-2 d * a * \sin \theta-a^{2} * \sin ^{2} \theta\right)^{\frac{1}{2}}}
\end{array}\right)
$$


The pressure drop due to the inertial effect of the rotating mass, $P_{\text {Rot }}$, can be analytically expressed based on the definition of pressure and the geometry indicated in Figure 3 as follows [29]:

$$
P_{\text {Rot }}=\frac{\left(m_{C P}+m_{C R}\right) * a * \cos \theta *\left(N_{m} * \frac{2 \pi}{60}\right)^{2}}{\pi *(B / 2)^{2}}
$$

where:

$m_{C P}$ is the mass of the protruded crank portion.

$m_{C R}$ is the mass of the connecting rod.

In addition, the pressure drop that takes place in the cylinder due to the air/gas flow losses, $P_{\text {Flow }}$, can be analytically formulated following from the first principles of physics. At $300 \mathrm{~K}$ and higher temperature up to $1000 \mathrm{~K}$, the compressibility factor of air remains equaling "1" as long as the pressure of air remains below 55 bar [30]. The cylinder's pressure during the intake stroke does not exceed 55 bar [26]. Thus, we can treat the air flow inside the intake system of the engine as incompressible fluid.

Let us consider two arbitrary points one and two on the stream of the air flow, one of them is in the intake manifold where the fluid medium is air and the other point is in the cylinder of the engine where the fluid medium is a mixture of air and atomized fuel. This is particularly true in light of the fact that early fuel injection is recommended for improved combustion. The pressure drop between these two points is analytically formulated following from the principle of conservation of energy and Bernoulli's equation that relates the changes in fluid, i.e., air, speed $(c)$ and fluid, i.e., air, pressure $(P)$ along the streamline [31]:

$$
\frac{P_{1}}{\rho}+\frac{c^{2} 1}{2}=\frac{P_{2}}{\rho}+\frac{c^{2}{ }_{2}}{2}
$$

Because one of these two points is considered stagnant relative to the other, this equation becomes:

$$
P_{\text {Flow }}=\frac{\bar{\rho} * c^{2}}{2}
$$

where: $\bar{\rho}$ is the arithmetic mean of fluid density between these two points, averaging the density of air $\left(\rho_{A}\right)$ and the density of atomized fuel $\left(\rho_{F}\right)$.

Because the geometry of the intake manifold plenum and runners and the shape of the intake valve opening together affect the fluid flow, this effect is taken into consideration in terms of the loss coefficient, $K_{L}$, that is introduced into Equation (16) as follows:

$$
P_{\text {Flow }}=K_{L} *\left(\frac{\bar{\rho} * c^{2}}{2}\right)
$$

The conservative value of the loss coefficient $K_{L}$ in this regard is about " 1.95 " for Tees Branch flow of fluid from the intake manifold plenum into the cylinders of the engine [32]. Thus, by combining Equations (1), (2), (13), (14), and (17) the pressure of the air that goes into cylinder $P_{\mathrm{Cyl}}$ can be formulated as follows:

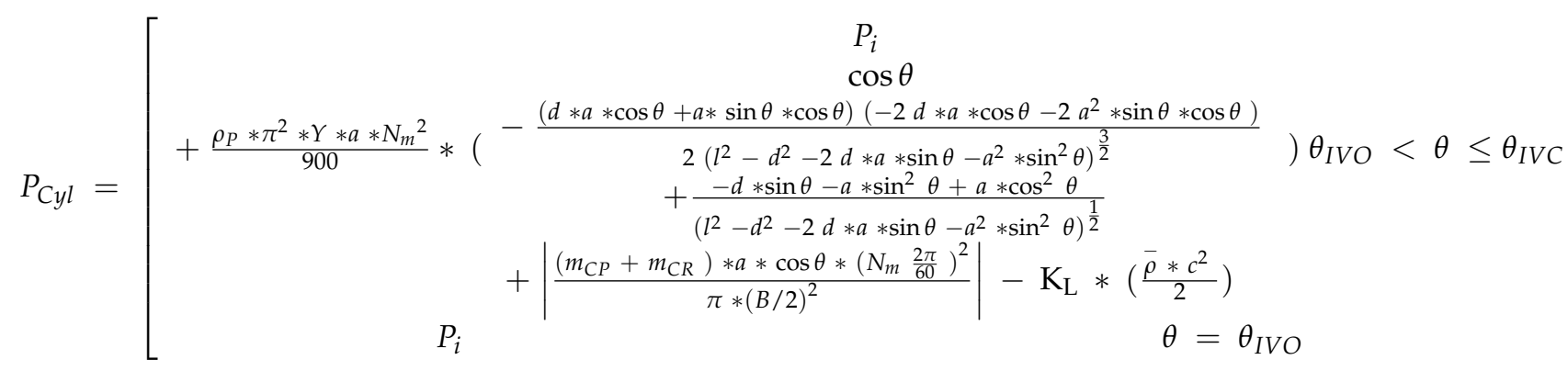

where:

$\theta_{I V C}$ is the rotational angle of the crankshaft at which the intake valve closes. 
$\theta_{I V O}$ is the rotational angle of the crankshaft at which the intake valve opens.

The mass flow rate of air that goes into one cylinder of the engine with a rigid crankshaft, $\dot{m}_{\mathrm{Cyl}}$, is analytically formulated in [33]:

$$
\dot{m}_{C y l}=\frac{P_{C y l} * \eta_{V} * V_{d} * N_{m} * n}{60 N_{C y l} * R * T_{i}}
$$

where:

$\eta_{V}$ is the volumetric efficiency of the engine.

$V_{d}$ is the displaced volume of the engine.

$n$ is the number of crank revolutions for each power stroke per cylinder (2 for four-stroke cycles; 1 for two-stroke cycles).

$N_{\text {Cyl }}$ is the number of cylinders in the internal combustion engine.

$R$ is the gas constant.

$T_{i}$ is the temperature of the air of the intake manifold.

Therefore, by combining Equations (18) and (19), the mass flow rate of the air that goes from intake manifold into all the cylinders of the engine with a flexible crankshaft, $\dot{m}_{A C}$, can be evaluated as:

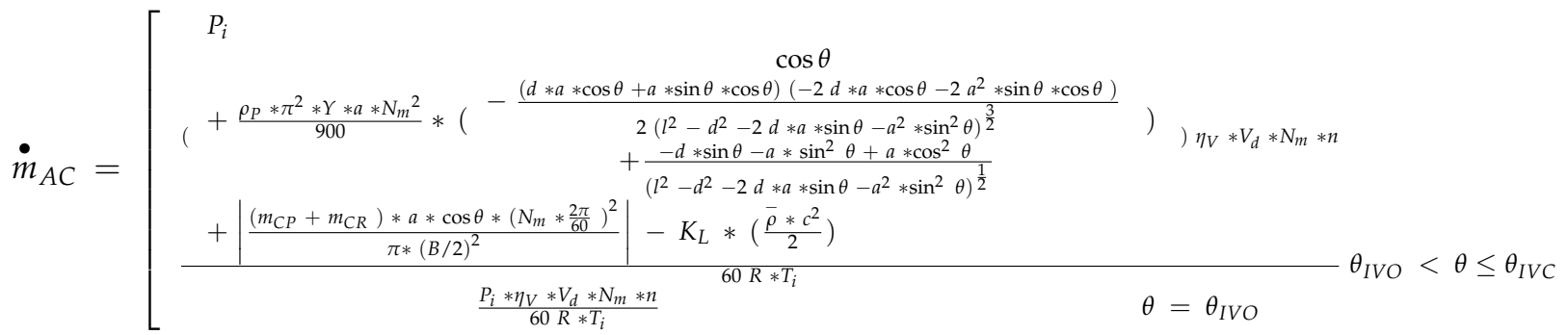

In order to simplify this developed model, a sensitivity analysis of which will be conducted in the next section.

\section{Sensitivity Analysis of the Developed Models}

A sensitivity analysis of the developed models in this study is conducted in this section for simplifying the developed models in order to suit control applications. The sensitivity analysis is based on applying the sensitivity ratio, $R_{S}$, to each of the independent variables. While evaluating $R_{S}$ for each independent variable. Meanwhile the values of the remaining independent variables remain unchanged from the baseline values. The $R_{S}$ is formulated as follows [34]:

$$
R_{S}=\frac{\frac{v_{D C}-v_{D B}}{v_{D B}}}{\frac{v_{I C}-v_{I B}}{v_{I B}}}
$$

where:

$v_{D C}$ is the value of the dependent variable in the analytical model with the increment/decrement of change.

$v_{D B}$ is the baseline value of the dependent variable in the analytical model.

$v_{I C}$ is the value of the independent variable in the analytical model with the increment/decrement of change.

$v_{I B}$ is the baseline value of the independent variable in the analytical model.

The Sensitivity analysis is conducted firstly on the developed model of $\dot{m}_{A C}$ at the crank angle of opening the intake valve $\theta_{I V O}$. The Sensitivity analysis on the developed model of $\dot{c}_{i m}$ then follows. 


\subsection{Sensitivity Analysis of the Developed Model of $\dot{m}_{A C}$}

The mass flow rate of air goes into all cylinders of the engine, $\dot{m}_{A C}$, is analytically modeled in Equation (20). The key explanatory variable in this model is $N_{m}$. As a recommended engine speed during the test for intake stroke, the baseline value of $N_{m}$ is $1550 \mathrm{rpm}$ [26]. The corresponding operating conditions are: $P_{C y l} 0.15 \times 10^{6} \mathrm{~N} / \mathrm{m}^{2}$ which is equivalent to a boosting pressure at rotational speed $1550 \mathrm{rpm}$ and compressor's adiabatic efficiency of 50\% in comparison with the naturally aspirated engines [35,36], $\eta_{V} 0.9, T_{i}$ $298 \mathrm{~K}$, and $V_{d} 0.0032 \mathrm{~m}^{3}$ [33]. The sensitivity analysis of the analytical model of $\dot{m}_{A C}$ at the crank angle of opening the intake valve $\theta_{I V O}$ is presented in Table 1 following from Equations (20) and (21).

Table 1. Sensitivity analysis of the analytical model of $\dot{m}_{A C}$ at the crank angle of opening the intake valve $\theta_{I V O}$.

\begin{tabular}{|c|c|c|c|c|c|c|}
\hline Variables & $\begin{array}{c}-50 \% \\
\text { Decrement } \\
\text { Below } \\
\text { Baseline Value }\end{array}$ & $\begin{array}{c}-25 \% \\
\text { Decrement } \\
\text { Below } \\
\text { Baseline Value }\end{array}$ & Baseline Value & $\begin{array}{c}+25 \% \\
\text { Increment } \\
\text { Above } \\
\text { Baseline Value }\end{array}$ & $\begin{array}{c}+50 \% \\
\text { Increment } \\
\text { Above } \\
\text { Baseline Value }\end{array}$ & $\begin{array}{c}\text { Average } \\
\text { Sensitivity } \\
\text { Ratio on Each } \\
\text { Independent } \\
\text { Variable }\end{array}$ \\
\hline $\begin{array}{c}P_{C y l}\left(\mathrm{~N} / \mathrm{m}^{2}\right) \\
\text { (Independent } \\
\text { Variable) }\end{array}$ & $0.075 \times 10^{6}$ & $0.11 \times 10^{6}$ & $0.15 \times 10^{6}$ & $0.187 \times 10^{6}$ & $0.225 \times 10^{6}$ & $\mathrm{~N} / \mathrm{A}$ \\
\hline $\begin{array}{l}\dot{m}_{A C}(\mathrm{~kg} / \mathrm{s}) \\
\text { (Dependent } \\
\text { Variable) }\end{array}$ & 0.0135 & 0.020 & 0.027 & 0.0337 & 0.040 & $\mathrm{~N} / \mathrm{A}$ \\
\hline $\begin{array}{c}R_{S} \text { on } \\
P_{C y l}\end{array}$ & 1 & 1 & $\mathrm{~N} / \mathrm{A}$ & 1 & 1 & 1 \\
\hline $\begin{array}{c}\eta_{V} \\
\text { (Independent } \\
\text { Variable) }\end{array}$ & 0.45 & 0.67 & 0.9 & 1.12 & 1.35 & $\mathrm{~N} / \mathrm{A}$ \\
\hline $\begin{array}{l}\dot{m}_{A C}(\mathrm{~kg} / \mathrm{s}) \\
\text { (Dependent } \\
\text { Variable) }\end{array}$ & 0.0135 & 0.020 & 0.027 & 0.0337 & 0.040 & $\mathrm{~N} / \mathrm{A}$ \\
\hline$R_{S}$ on $\eta_{V}$ & 1 & 1 & $\mathrm{~N} / \mathrm{A}$ & 1 & 1 & 1 \\
\hline $\begin{array}{c}V_{d}\left(\mathrm{~m}^{3}\right) \\
\text { (Independent } \\
\text { Variable) }\end{array}$ & 0.0016 & 0.0024 & 0.0032 & 0.004 & 0.0048 & $\mathrm{~N} / \mathrm{A}$ \\
\hline $\begin{array}{c}\dot{m}_{A C}(\mathrm{~kg} / \mathrm{s}) \\
\text { (Dependent } \\
\text { Variable) }\end{array}$ & 0.0135 & 0.020 & 0.027 & 0.0337 & 0.040 & $\mathrm{~N} / \mathrm{A}$ \\
\hline$R_{S}$ on $V_{d}$ & 0.997 & 0.96 & $\mathrm{~N} / \mathrm{A}$ & 1.01 & 1.04 & 1 \\
\hline $\begin{array}{c}T_{i}(\mathrm{~K}) \\
\text { (Independent } \\
\text { Variable) }\end{array}$ & 149 & 223.5 & 298 & 372.5 & 447 & $\mathrm{~N} / \mathrm{A}$ \\
\hline $\begin{array}{l}\dot{m}_{A C}(\mathrm{~kg} / \mathrm{s}) \\
\text { (Dependent } \\
\text { Variable) }\end{array}$ & 0.054 & 0.036 & 0.027 & 0.022 & 0.018 & $\mathrm{~N} / \mathrm{A}$ \\
\hline$R_{S}$ on $T_{i}$ & -0.5 & -0.78 & $\mathrm{~N} / \mathrm{A}$ & -1 & -1.4 & -0.92 \\
\hline
\end{tabular}

It is noteworthy that the term "N/A" in Table 1 technically means "Not Applicable", that is the cell labeled with "N/A" cannot logically carry a feasible value of the specific variable indicated in the respective horizontal line that simultaneously represents the header of the respective column of this cell. The term "N/A" thus does not mean missing 
data or unavailability of data. Therefore, the dependent variable, $\dot{m}_{A C}$, is sensitive to the changes in the value of the independent variables. Thus, the simplified analytical model of $\dot{m}_{A C}$ remains the same as Equation (20). The simplified analytical model of $\dot{m}_{A C}$ is hence formulated in Equation (20).

\subsection{Sensitivity Analysis of the Developed Model of ${ }^{\bullet}{ }_{i m}$}

The intake manifold air speed dynamics, i.e., acceleration, in diesel engines, $\dot{c}_{i m}$ in $\mu \mathrm{m} / \mathrm{s}^{2}$, is analytically modeled in another research paper of the authors [19]:

$$
\dot{c_{i m}}=\frac{P_{i}}{\rho_{A} * L}-\frac{2 \zeta * c^{2}}{D}
$$

where:

$\rho_{A}$ is the density of air inside the intake manifold $\left(\mathrm{kg} / \mathrm{m}^{3}\right)$.

$\frac{D}{L}$ is the ratio of the diameter of plenum of intake manifold to the length of intake manifold.

$\zeta$ is the flow friction coefficient.

The key explanatory variable in this model is $c$. The baseline value of $c$ is $30 \mathrm{~m} / \mathrm{s}$. The corresponding operating conditions are: $P_{i} 0.1 \times 10^{6} \mathrm{~N} / \mathrm{m}^{2}, \zeta 0.55, \eta_{V} 0.9, T_{i} 298 \mathrm{~K}$, $\mathrm{D} / L 0.2$, and $V_{d} 0.00272 \mathrm{~m}^{3}[19,35,36]$. The sensitivity analysis of the analytical model of $\dot{c}_{i m}$ is presented in Table 2 following from Equations (22) and (21).

It is noteworthy that the term "N/A" in Table 2 technically means "Not Applicable", that is the cell labeled with "N/A" cannot logically carry a feasible value of the specific variable indicated in the respective horizontal line that simultaneously represents the header of the respective column of this cell. Thus, $\dot{c}_{i m}$ is insensitive to the changes in the value of $\zeta$. Hence, $\zeta$ should be considered a constant in the formulation of $\dot{c}_{i m}$. The $\dot{\boldsymbol{c}}_{i m}$ is, however, sensitive to the changes in the value of $P_{i}, \rho_{A}, L$, and $D$. Hence, $P_{i}, \rho_{A}, L$, and $D$ should not be considered constants in the formulation of $\dot{c}_{i m}$. The simplified analytical model of the acceleration of air in the intake manifold of diesel engines, $\dot{c}_{i m}$, can be therefore formulated as follows:

$$
\dot{c}_{i m}=\frac{P_{i}}{\rho_{A} * L}-1.1 \frac{c^{2}}{D}
$$

The gas speed $c$ indicated in Equation (23) is formulated as:

$$
c=\frac{Q_{i m}}{\frac{\pi}{4} D^{2}}
$$

Having seen the simplified formulation of the developed model of $c_{i m}$, let us now investigate the experimental validation of the developed model through a case study and the statistical analysis thereon. 
Table 2. Sensitivity analysis of the analytical model of $\stackrel{\bullet}{i m}^{\circ}$.

\begin{tabular}{|c|c|c|c|c|c|c|}
\hline Variables & $\begin{array}{c}-50 \% \\
\text { Decrement } \\
\text { Below } \\
\text { Baseline Value }\end{array}$ & $\begin{array}{c}-25 \% \\
\text { Decrement } \\
\text { Below } \\
\text { Baseline Value }\end{array}$ & Baseline Value & $\begin{array}{c}+25 \% \\
\text { Increment } \\
\text { Above } \\
\text { Baseline Value }\end{array}$ & $\begin{array}{c}+50 \% \\
\text { Increment } \\
\text { Above } \\
\text { Baseline Value }\end{array}$ & $\begin{array}{c}\text { Average } \\
\text { Sensitivity } \\
\text { Ratio on Each } \\
\text { Independent } \\
\text { Variable }\end{array}$ \\
\hline $\begin{array}{c}{\stackrel{\bullet}{c_{i m}}}^{(D e p e n d e n t} \\
\text { Variable) }\end{array}$ & 0.058 & 0.095 & $0.131 \mathrm{~m} / \mathrm{s}^{2}$ & 0.167 & 0.204 & $\mathrm{~N} / \mathrm{A}$ \\
\hline $\begin{array}{c}P_{i} \\
\text { (Independent } \\
\text { Variable) }\end{array}$ & $0.05 \times 10^{6}$ & $0.075 \times 10^{6}$ & $0.1 \times 10^{6} \mathrm{~N} / \mathrm{m}^{2}$ & $0.125 \times 10^{6}$ & $0.15 \times 10^{6}$ & $\mathrm{~N} / \mathrm{A}$ \\
\hline$R_{S}$ on $P_{i}$ & 1.1 & 1.1 & $\mathrm{~N} / \mathrm{A}$ & 1.1 & 1.1 & 1.1 \\
\hline $\begin{array}{c}\stackrel{\bullet}{c}_{i m} \\
\text { (Dependent } \\
\text { Variable) }\end{array}$ & 0.276 & 0.179 & $0.131 \mathrm{~m} / \mathrm{s}^{2}$ & 0.102 & 0.083 & $\mathrm{~N} / \mathrm{A}$ \\
\hline $\begin{array}{c}\rho_{A} \\
\text { (Independent } \\
\text { Variable) }\end{array}$ & 0.85 & 1.29 & $1.75 \mathrm{~kg} / \mathrm{m}^{3}$ & 2.19 & 2.55 & $\mathrm{~N} / \mathrm{A}$ \\
\hline$R_{S}$ on $\rho_{A}$ & -2.2 & -1.47 & $\mathrm{~N} / \mathrm{A}$ & -0.9 & -0.7 & -1.3 \\
\hline $\begin{array}{c}\stackrel{\bullet}{\dot{c}_{i m}} \\
\text { (Dependent } \\
\text { Variable) }\end{array}$ & 0.276 & 0.179 & $0.131 \mathrm{~m} / \mathrm{s}^{2}$ & 0.102 & 0.083 & $\mathrm{~N} / \mathrm{A}$ \\
\hline $\begin{array}{c}L \\
\text { (Independent } \\
\text { Variable) } \\
\end{array}$ & 0.2 & 0.3 & $0.4 \mathrm{~m}$ & 0.5 & 0.6 & $\mathrm{~N} / \mathrm{A}$ \\
\hline$R_{S}$ on $L$ & -2.2 & -1.47 & $\mathrm{~N} / \mathrm{A}$ & -0.9 & -0.7 & -1.3 \\
\hline $\begin{array}{c}\dot{\bullet}_{i m} \\
\text { (Dependent } \\
\text { Variable) }\end{array}$ & 0.138 & 0.134 & $0.131 \mathrm{~m} / \mathrm{s}^{2}$ & 0.127 & 0.124 & $\mathrm{~N} / \mathrm{A}$ \\
\hline $\begin{array}{c}\zeta \\
\text { (Independent } \\
\text { Variable) }\end{array}$ & 0.28 & 0.41 & 0.55 & 0.69 & 0.83 & $\mathrm{~N} / \mathrm{A}$ \\
\hline$R_{S}$ on $\zeta$ & 0 & 0 & $\mathrm{~N} / \mathrm{A}$ & 0 & 0 & 0 \\
\hline $\begin{array}{c}{\stackrel{\bullet}{c_{i m}}}_{\text {(Dependent }} \\
\text { Variable) }\end{array}$ & 0.117 & 0.126 & $0.131 \mathrm{~m} / \mathrm{s}^{2}$ & 0.134 & 0.136 & $\mathrm{~N} / \mathrm{A}$ \\
\hline $\begin{array}{c}D \\
\text { (Independent } \\
\text { Variable) }\end{array}$ & 0.040 & 0.060 & $0.080 \mathrm{~m}$ & 0.100 & 0.120 & $\mathrm{~N} / \mathrm{A}$ \\
\hline$R_{S}$ on $D$ & 0.21 & 0.2 & $\mathrm{~N} / \mathrm{A}$ & 0.1 & 0.1 & 0.2 \\
\hline
\end{tabular}

6. Statistically Analyzed Experimental Validation of the Developed Models of $\dot{m}_{A C}$ and $\boldsymbol{c}_{i m}$ through a Case Study

The analytical model of $\dot{m}_{A C}$ developed in Equation (20) and the analytical model of $\dot{c_{i m}}$ presented in Equation (23) are validated in this section. The validation would be conducted through experimental case studies and the results would be analyzed statistically. 


\subsection{Statistically Analyzed Experimental Validation of the Developed Model of $\dot{m}_{A C}$}

The experimental validation of the analytical model of $\dot{m}_{A C}$ developed in Equation (20) is investigated in this section. A case study has been conducted based on the four-cylinder 3.2 L Mitsubishi 4M4 engine [37]. Field data that represent operating points of rotational speed of $1550 \mathrm{rpm}$ and compressor's adiabatic efficiency of 50\% are shown in Table 3 [36]. The engine speed of $1550 \mathrm{rpm}$ is a recommended engine speed during the test for intake stroke [26]. This rotational speed is approximately the average speed of such four-cylinder diesel engines [15,38]. The length of connecting rod $(l)$ is $0.148 \mathrm{~m}$ and the crank length $(\alpha)$ is $0.048 \mathrm{~m}$ [39]. The piston's material density $\left(\rho_{P}\right)$ is $2700 \mathrm{~kg} / \mathrm{m}^{3}$ and the piston's characteristic height $(Y)$ is $0.055 \mathrm{~m}$ [39]. Based on the torsional deformation that reflects the amplitude of the rigid body motion of the center of the crank shaft, the flexibility of the crankshaft $(D)$ is $2 \times 10^{-4} \mathrm{~m}$ [40]. This very small value of the $(d)$ corresponds to the reported very small angular deformation of the crankshaft of about $0.2^{\circ}$ in average [40]. The cylinder (bore) diameter $(B)$ is $0.098 \mathrm{~m}$ [37]. The summation of the mass of piston, mass of connecting rod and mass of crank pin collectively is $2.95 \mathrm{~kg}$ [40]. The molar weight of air is $0.0289 \mathrm{~kg} / \mathrm{mol}$.

Mechanical superchargers can operate up to the compressor's impeller speed of $100,000 \mathrm{rpm}$ [41]. The supercharger boosting pressure is not constant, since it depends on the speed of the supercharger impeller which in turn is driven by the crankshaft through a belt [42]. The faster the supercharger's impeller rotates, the higher the boosting pressure would be. The supercharger efficiency becomes lower during operation, because the crankshaft rotational speed fluctuates and engine's accessories such as the supercharger have moments of inertia, so that belts slip on pulleys. Thus, this results in wear, power loss and reduced efficiency. Thus, in the intake stroke we aim at almost $50 \%$ boosting pressure (i.e., $P i=1.5$ bar) at relatively high efficiency of $67 \%[36,43]$.

Table 3. Field data on a case study conducted with respect to $\dot{m}_{A C}$.

\begin{tabular}{|c|c|c|}
\hline \multirow{2}{*}{$\begin{array}{c}\text { Parameter } \\
P_{i}\end{array}$} & \multicolumn{2}{|c|}{$\begin{array}{l}\text { Average Value Extracted from Field Data during the } \\
\text { Intake Stroke }\end{array}$} \\
\hline & $0.15 \times 10^{6} \mathrm{~N} / \mathrm{m}^{2}$ & [26] \\
\hline$V_{d}$ & $3.2 \times 10^{-3} \mathrm{~m}^{3}$ & {$[26,33]$} \\
\hline$N_{m}$ & $1550 \mathrm{rpm}$ & [26] \\
\hline$T_{i}$ & $298 \mathrm{~K}$ & [26] \\
\hline$\rho_{A}$ & $1.75 \mathrm{~kg} / \mathrm{m}^{3}$ & [36] \\
\hline$\rho_{F}$ & $832 \mathrm{~kg} / \mathrm{m}^{3}$ & [5] \\
\hline$\eta_{V}$ & 0.9 & {$[33,44]$} \\
\hline$Q_{i m}$ & $40 \times 10^{-3} \mathrm{~m}^{3} / \mathrm{s}$ & [45] \\
\hline
\end{tabular}

For checking the consistency of the developed analytical model with the experimental and field data, the range of the crankshaft rotational angle $(\theta)$ would be equally and symmetrically divided into a few segments [22]. Thus, the developed model would be tested at the following values of $\theta$ : (1) At $\theta_{1}=360^{\circ}$ when the intake valve is opened [46,47], (2) At $\theta_{2}=405^{\circ}$, (3) At $\theta_{3}=450^{\circ}$, (4) At $\theta_{4}=495^{\circ}$ when the intake valve is closed $[46,47]$. For a volumetric flow rate of air in the intake manifold per cylinder, $Q_{i m}$, of $40 \times 10^{-3} \mathrm{~m}^{3} / \mathrm{s}$ the gas speed, $c$, becomes $30 \mathrm{~m} / \mathrm{s}$ according to Equation (24). Therefore, following from Equation (20) and Table 3, for the four-stroke thermodynamic cycle, the mass flow rate of the air that goes from intake manifold into all the cylinders of the engine, $\dot{m}_{A C}$, would be evaluated at each of these values of $\theta$. At $\theta_{1}=360^{\circ}$ when the intake valve is opened:

$$
\dot{m}_{A C}=\frac{\left(0.15 * 10^{6} \frac{\mathrm{N}}{\mathrm{m}^{2}}\right)(0.9)\left(0.0032 \mathrm{~m}^{3}\right)\left(1550 * \frac{2 \pi}{60} \frac{\mathrm{rad}}{\mathrm{s}}\right)\left(0.0289 \frac{\mathrm{kg}}{\mathrm{mol}}\right)(2)}{60\left(8.3145 \frac{\mathrm{N} \mathrm{m}}{\mathrm{mol} \mathrm{K}}\right)(298 \mathrm{~K})}=0.027 \mathrm{~kg} / \mathrm{s}
$$


At $\theta_{2}=405^{\circ}$ :

$$
\begin{gathered}
{\left[\left(0.15 * 10^{6} \frac{\mathrm{N}}{\mathrm{m}^{2}}\right)+\left(1439 \frac{\mathrm{N}}{\mathrm{m}^{2}}\right)+\left|349672 \frac{\mathrm{N}}{\mathrm{m}^{2}}\right|-\left(365742 \frac{\mathrm{N}}{\mathrm{m}^{2}}\right)\right]} \\
\dot{m}_{A C} \quad \frac{(0.9)\left(0.0032 \mathrm{~m}^{3}\right)\left(1550 * \frac{2 \pi}{\mathrm{og}} \frac{\mathrm{rad}}{\mathrm{s}}\right)\left(0.0289 \frac{\mathrm{kg}}{\mathrm{mol}}\right)(2)}{60\left(8.3145 \frac{\mathrm{Nol}}{\mathrm{m}}\right)(298 \mathrm{~K})} \\
=\frac{\left[131052 \frac{\mathrm{N}}{\mathrm{m}^{2}}\right](0.9)\left(0.0032 \mathrm{~m}^{3}\right)\left(1550 * \frac{2 \pi}{60} \frac{\mathrm{rad}}{\mathrm{s}}\right)\left(0.0289 \frac{\mathrm{kg}}{\mathrm{mol}}\right)(2)}{60\left(8.3145 \frac{\mathrm{Nm}}{\mathrm{mol} \mathrm{K}}\right)(298 \mathrm{~K})} \\
=0.0243 \mathrm{~kg} / \mathrm{s}
\end{gathered}
$$

At $\theta_{3}=450^{\circ}$ :

Within the range of the crankshaft rotational angles in the intake stroke, this crankshaft rotational angle is a singular and inflection point at which the fluid that flows from the manifold plenum into the cylinders of the engine switches from Tees Branch flow to Tees Line flow. This results in even further reduction of the $\dot{m}_{A C}$ inside the cylinders of the engine. Thus, the coefficient of flow loss, $K_{L}$, becomes 0.25 rather than 1.95 [32].

$$
\begin{gathered}
{\left[\left(0.15 * 10^{6} \frac{\mathrm{N}}{\mathrm{m}^{2}}\right)+\left(-2.8 \frac{\mathrm{N}}{\mathrm{m}^{2}}\right)+\left|0 \frac{\mathrm{N}}{\mathrm{m}^{2}}\right|-\left(46890 \frac{\mathrm{N}}{\mathrm{m}^{2}}\right)\right]} \\
\dot{m}_{A C} \quad \frac{(0.9)\left(0.0032 \mathrm{~m}^{3}\right)\left(1550 * \frac{2 \pi}{60} \frac{\mathrm{rad}}{\mathrm{s}}\right)\left(0.0289 \frac{\mathrm{kg}}{\mathrm{mol}}\right)(2)}{60\left(8.3145 \frac{\mathrm{Nol}}{\mathrm{m}}\right)(298 \mathrm{~K})} \\
=\frac{\left[103107 \frac{\mathrm{N}}{\mathrm{m}^{2}}\right](0.9)\left(0.0032 \mathrm{~m}^{3}\right)\left(1550 * \frac{2 \pi}{60} \frac{\mathrm{rad}}{\mathrm{s}}\right)\left(0.0289 \frac{\mathrm{kg}}{\mathrm{mol}}\right)(2)}{60\left(8.3145 \frac{\mathrm{Nm}}{\mathrm{mol} \mathrm{K}}\right)(298 \mathrm{~K})} \\
=0.019 \mathrm{~kg} / \mathrm{s}
\end{gathered}
$$

At $\theta_{4}=495^{\circ}$ when the intake valve is closed:

\begin{tabular}{|c|c|c|}
\hline Standard Cycles & Standard Cycles Result & Average Result of the Analytical Model \\
\hline $\begin{array}{c}\text { ORNL and EPA Freeway LOS } \\
\text { A-C drive cycles (Average Speed } \\
95.52 \mathrm{~km} / \mathrm{h} \text { ) [33] }\end{array}$ & $\begin{array}{l}\text { The Air/Fuel ratio is } 15 \text { [33]. Based on the } \\
\text { four-cylinder } 3.2 \mathrm{~L} \text { Mitsubishi } 4 \mathrm{M} 4 \text { engine, the } \\
\text { fuel mass flow rate as read from field data is } \\
0.00165 \mathrm{~kg} / \mathrm{s}[33,37] \text {. Thus, the mass flow rate of } \\
\text { air that goes into all cylinders of the engine } \dot{m}_{A C} \\
\text { is }(0.00165 \mathrm{~kg} / \mathrm{s} \times 15) \text { that is } 0.025 \mathrm{~kg} / \mathrm{s} \text {. }\end{array}$ & $\begin{array}{l}\text { The average value of the modeled } \dot{m}_{A C} \text { is } \\
\qquad 0.024 \mathrm{~kg} / \mathrm{s} \text {. }\end{array}$ \\
\hline $\begin{array}{l}\text { ORNL and EPA Freeway High } \\
\text { Speed drive cycle } \\
\text { (Average Speed } 101 \mathrm{~km} / \mathrm{h} \text { ) [32] }\end{array}$ & $\begin{array}{l}\text { The Air/Fuel ratio is } 15 \text { [33]. Based on the } \\
\text { four-cylinder } 3.2 \mathrm{~L} \text { Mitsubishi } 4 \mathrm{M} 4 \text { engine, the } \\
\text { fuel mass flow rate as read from field data is } \\
0.0018 \mathrm{~kg} / \mathrm{s}[33,37] \text {. Thus, the mass flow rate of } \\
\text { air that goes into all cylinders of the engine } \dot{m}_{A C} \\
\text { is }(0.0018 \mathrm{~kg} / \mathrm{s} \times 15) \text { that is } 0.027 \mathrm{~kg} / \mathrm{s} \text {. }\end{array}$ & $\begin{array}{l}\text { The average value of the modeled } \dot{m}_{A C} \text { is } \\
\qquad 0.024 \mathrm{~kg} / \mathrm{s} \text {. }\end{array}$ \\
\hline
\end{tabular}

$$
\begin{gathered}
{\left[\left(0.15 * 10^{6} \frac{\mathrm{N}}{\mathrm{m}^{2}}\right)+\left(-1439 \frac{\mathrm{N}}{\mathrm{m}^{2}}\right)+\left|-349672 \frac{\mathrm{N}}{\mathrm{m}^{2}}\right|-\left(365742 \frac{\mathrm{N}}{\mathrm{m}^{2}}\right)\right]} \\
\dot{m}_{A C} \quad \frac{(0.9)\left(0.0032 \mathrm{~m}^{3}\right)\left(1550 * \frac{2 \pi}{60} \frac{\mathrm{rad}}{\mathrm{s}}\right)\left(0.0289 \frac{\mathrm{kg}}{\mathrm{mol}}\right)(2)}{60\left(8.3145 \frac{\mathrm{N} m \mathrm{~K}}{\mathrm{~mol}}\right)(298 \mathrm{~K})} \\
=\frac{\left[132491 \frac{\mathrm{N}}{\mathrm{m}^{2}}\right](0.9)\left(0.0032 \mathrm{~m}^{3}\right)\left(1550 * \frac{2 \pi}{6} \frac{\mathrm{rad}}{\mathrm{s}}\right)\left(0.0289 \frac{\mathrm{kg}}{\mathrm{mol}}\right)(2)}{60\left(8.3145 \frac{\mathrm{N} \mathrm{m}}{\mathrm{mol} K}\right)(298 \mathrm{~K})} \\
=0.0246 \mathrm{~kg} / \mathrm{s}
\end{gathered}
$$

In order to validate this analytical model, the modeling results are compared with the corresponding values of the standard ORNL and EPA Freeway LOS A-C drive cycles. This comparison is illustrated in Table 4.

Table 4. Comparison of the modeling results and the results of standard cycles on $\dot{m}_{A C}$. 
The statistical measure in this research work is the relative error of the model, $\varepsilon_{R}$, that can be evaluated as follows [48]:

$$
\varepsilon_{R}=\sum_{i=1}^{z_{n}}\left|\frac{y_{i}-x_{i}}{y_{i}}\right| \frac{100 \%}{z_{n}}
$$

where:

$x_{i}$ is the interval variable which is the analytically expected value.

$y_{i}$ is the interval variable that is the measured value, i.e., field dataset.

$z_{n}$ is the number of records in the sample.

The $\varepsilon_{R}$ is utilized in this study as a quantifiable measure of validation. The comparison of the data of the case study and standard cycles with the results of the developed model of $\dot{m}_{A C}$ is statistically analyzed in Table 5 .

Table 5. Summary of the statistical analysis on $\dot{m}_{A C}$.

\begin{tabular}{|c|c|c|c|}
\hline Table & $\bar{x}$ & $\bar{y}$ & $\varepsilon_{R}$ \\
\hline $\begin{array}{c}\text { Table 4, ORNL and EPA Freeway } \\
\text { LOS A-C drive cycles }\end{array}$ & $0.024 \mathrm{~kg} / \mathrm{s} . \mathrm{kg} / \mathrm{s}$ & $0.025 \mathrm{~kg} / \mathrm{s}$ & $4 \%$ \\
\hline $\begin{array}{c}\text { Table 4, ORNL and EPA Freeway } \\
\text { High Speed drive cycle }\end{array}$ & $0.024 \mathrm{~kg} / \mathrm{s} . \mathrm{kg} / \mathrm{s}$ & $0.027 \mathrm{~kg} / \mathrm{s}$ & $11 \%$ \\
\hline & & & $7.5 \%$ \\
\hline
\end{tabular}

Where:

$\bar{x}$ is the average value of the interval variable which is the analytically expected value. $\bar{y}$ is the average value of the interval variable that is the measured value, i.e., field dataset.

\subsection{Statistically Analyzed Experimental Validation of the Developed Model of $\dot{c}_{\text {im }}^{\bullet}$}

The experimental validation of the analytical model of $c_{i m}$ presented in Equation (23) is investigated in this section. A case study has been conducted based on the $200 \mathrm{cc}$ FourStroke Single Cylinder Go Kart ATV Jeep 2016 [49]. Field data that represent an operating point of rotational speed of $2500 \mathrm{rpm}$ and compressor's adiabatic efficiency of $50 \%$ are shown in Table 6. This rotational speed is the average speed of such diesel engines. Because the diesel engine is usually operated at wide-open throttle, the corresponding air flow's acceleration in the intake manifold ranges from slow to medium acceleration.

Table 6. Field data on a case study conducted with respect to $\dot{c}_{i m}$.

\begin{tabular}{ccc}
\hline Parameter & $\begin{array}{c}\text { Average Value Extracted from Field Data During the Intake } \\
\text { Stroke }\end{array}$ \\
\hline$c_{i m}$ & $\begin{array}{c}0.185 \mathrm{~m} / \mathrm{s}^{2}, \text { on average for low to } \\
\text { medium flow's acceleration }\end{array}$ & {$[50]$} \\
\hline$P_{i}$ & $0.155 \times 10^{6} \mathrm{~N} / \mathrm{m}^{2}$ & {$[45]$} \\
\hline$\frac{D}{L}$ & $65 \mathrm{~mm} / 400 \mathrm{~mm}, \mathrm{i} . e ., 0.2$ & {$[35]$} \\
\hline$Q_{i m}$ & $40 \times 10^{-3} \mathrm{~m}^{3} / \mathrm{s}$ & {$[45]$} \\
\hline$\zeta$ & 0.55 & {$[36]$} \\
\hline$\rho_{A}$ & $1.8 \mathrm{~kg} / \mathrm{m}^{3}$ & {$[35,36]$} \\
\hline$\eta_{C A}$ & $50 \%$ &
\end{tabular}


Where:

$\eta_{C A}$ is the compressor's adiabatic efficiency.

An intercooler is often used at the outlet of the supercharging compressor for maintaining the air temperature drawn into the intake manifold to be on average below $35{ }^{\circ} \mathrm{C}$ under severe driving conditions [51]. In average the corresponding compressor's pressure ratio at the operating point in the intake manifold becomes about 1.5.

Based on Equations (23) and (24) and Table 6, the analytical value of $\dot{c}_{i m}$ for the engine is shown in Table 7 . The positive sign of $\dot{c}_{i m}^{\bullet}$ indicates accelerated flow. The comparison of the data of the case study with the results of the developed model of $\dot{c}_{i m}^{\bullet}$ is statistically analyzed in Table 7 based on Equation (25).

Table 7. Summary of the statistical analysis on $\dot{c_{i m}}$.

\begin{tabular}{cccc}
\hline Table & $\bar{x}$ & $\bar{y}$ & $\varepsilon_{\boldsymbol{R}}$ \\
\hline Table 4 & $0.21 \mathrm{~m} / \mathrm{s}^{2}$ & $0.185 \mathrm{~m} / \mathrm{s}^{2}$ & $11 \%$ \\
\hline
\end{tabular}

\section{Discussion}

The analytical model presented in the present paper favourably facilitates the endeavours of improving the performance of diesel engines towards having environmentally friendly diesel engines. Such an analytical approach to modeling is favourably adopted in automotive and environmental engineering [52]. The present paper has thus presented the analytical modeling of the diesel engine intake manifold with a flexible crankshaft. The analytical models presented in this paper have followed from the first principles of physics as a way of further validating the developed models. The paper has started with the analytical modeling of the mass flow rate of air goes into cylinders with a flexible crankshaft indicated in Equation (20). The distance " $\mathrm{d}$ " indicated in Figure 3 represents the flexibility of the crankshaft. The nonlinearities brought to the analysis of diesel engine intake manifold due to the flexibility of the crankshaft in diesel engines are apparent in the analytical model of the piston's instantaneous linear velocity, $S_{\mathrm{P}}$, shown in Equation (8). The analytical model of the intake manifold gas speed acceleration, $\dot{c}_{i m}$, has been simplified in Equation (23) based on the sensitivity analysis. The $\dot{c}_{i m}^{\bullet}$ has been formulated for the critical moment at which the largest moment is exerted on the crankshaft.

The analytical model developed in Equation (1) indicates that the pressure of the gas inside the cylinder during the intake stroke has a driving element and draining elements. The driving element is the intake manifold pressure. The draining elements are: (i) the vacuum pressure that results from the piston's inertia and acceleration, (ii) the pressure drop that takes place in the cylinder due to the air/gas flow losses, (iii) the pressure influence due to the inertial effect of the rotating mass. The experimental validation "Section 6.1" indicates that the element of the least effect amongst these four elements is the vacuum pressure that results from the piston's inertia and acceleration. The experimental validation section "Section 6.1" also indicates that the elements of the largest effect amongst these four elements is the pressure drop that takes place in the cylinder due to the air/gas flow losses.

The developed model of $\dot{m}_{A C}$ has been validated as well through a case study and the ORNL and EPA Freeway standard drive cycles and the $\varepsilon_{R}$ on $\dot{m}_{A C}$ has been $7.5 \%$ as indicated in Table 5 which is less than that of widely recognized models in this field such as the CMEM [18] and and the GT-Power [53]. Table 5 and Equation (20) indicate that the influence of $P_{\text {Rot }}$ on $P_{C y l}$ is larger than the influence of $P_{V a c}$ on $P_{C y l}$.

As proven in Table 5 through the crank angle of the crankshaft, the flexibility of the crankshaft decreases $\dot{m}_{A C}$, resulting in unfavorable higher rate of exhaust emissions. This is proven is several senses. As mentioned in the couple of lines succeeding Equation (4), the flexibility of the crankshaft is represented in the distance " $\mathrm{d}$ " indicated in Figure 3. As can be gathered from Figure 3, the distance " $\mathrm{d}$ " indicated in Figure 3 vanishes 
at $\theta=\theta_{I V O}=360^{\circ}$ (i.e., $=0^{\circ}$ ), so that the influence of flexibility does not appear. As $\theta$ increases therefrom, the distance " $\mathrm{d}$ " indicated in Figure 3 increases, so that the influence of flexibility becomes apparent. Thus, following from Section 6.1, by comparing the mass flow rate of air that goes into cylinders in the cases of varying $\theta$, the flexibility of the crankshaft decreases the mass flow rate of air that goes into cylinders. This decrease in the mass flow rate of air negatively influences the actual Air/Fuel ratio increasing the Air/Fuel ratio. This decrease in the mass flow rate of air is in the range of up to $10 \%$, as can be gathered from the results in Section 6.1. Thus, this decrease in the Air/Fuel ratio reduces the output power and exhibits unfavorable higher rate of exhaust emissions, such as $\mathrm{CO}$ exhaust emission [54,55]. Carbon monoxide (CO) emissions results from incomplete combustion due to incomplete oxidation. The $\mathrm{CO}$ concentration is basically dependent on air/fuel mixture and is highest where the air/fuel ratio is less than the stoichiometric concentration, which is classified as "rich mixture" [54]. In the rich mixture, due to air deficiency and reactant concentration, not all Carbon atoms can form $\mathrm{CO}_{2}$ molecules, so that the concentration of the $\mathrm{CO}$ molecules becomes noticeable. The $\mathrm{CO}$ emissions are caused especially at the times of starting and instantaneous acceleration of engine where the rich mixture is required [54]. This makes sense and is in accord with the present results since under the transient condition, the operational vibrations become higher which result in higher deflection in the crankshaft which in turn results in reduction in the air/fuel ratio which eventually causes a higher rate of $\mathrm{CO}$ emissions. The increase in $\mathrm{CO}$ exhaust emission occurs also with bio-diesel fuel [56]. The lower value of $P_{C y l}$ due to the crankshaft flexibility when the crank rotational angle becomes larger than $\theta_{I V O}$ further explains the decrease in the mass flow rate of air. The influence of the flexibility of the crankshaft on the mass flow rate of gas in cylinders, would be even more pronounced in case of bio-fuel/biodiesel since the organic oil viscosity is several times higher than that of diesel fuel [57]. Given the result that the flexibility of the crankshaft decreases the mass flow rate of air that goes into cylinders, resulting in unfavorable higher rate of exhaust emission, strengthening the microstructure of the crankshaft with nano-I-beam is expected to improve the flexural stiffness and strength of the crankshaft. This would result in longer service life along with exhaust emission reduction $[58,59]$.

The developed model of $\dot{c_{i m}}$ has been validated as well through a case study and the $\varepsilon_{R}$ on $\dot{c_{i m}}$ has been $11 \%$ as indicated in Table 7 which is less than that of widely recognized models in this field such as the CMEM [18]. Equation (23) has implied that the influence of $P_{i}, \rho_{A}$, and $L$ on $\hat{c}_{i m}$ is as much as about $90 \%$. Equation (23) has also implied that the influence of $\zeta, c$, and $D$ is as little as about $10 \%$. The developed analytical model of $\dot{c}_{i m}$ improves on corresponding analytical models presented in key references in this field, such as [60]. Such results can help in realizing an accurate prediction of fuel injection and spray characteristics in diesel engines. Such an accurate prediction results in an accurate prediction of pollutants of these engines [61].

\section{Conclusions}

The present study has presented and validated the analytical modeling of the intake manifold of a supercharged diesel engine taking into account the nonlinearities exhibited due to the flexibility of the crankshaft. The following achievements have been accomplished in this paper: (I) the study has analytically modeled the mass flow rate of the air that goes into cylinders with a flexible crankshaft; (II) a simplified version for control applications of the analytical models of both the mass flow rate of the air that goes from intake manifold into all the cylinders $\left(\dot{m}_{A C}\right)$ and gas speed dynamics of the engine $\left(c_{i m}^{\bullet}\right)$ has been developed based on a sensitivity analysis; (III) the relative errors of the developed models are $7.5 \%$ and $11 \%$, which are on average less than that of key models such as the GT-Power and the CMEM, respectively; (IV) validating these developed analytical models using case studies and the ORNL and EPA Freeway standard drive cycles and analyzing the simulated results statistically; (V) the paper captures the influence of the flexibility of the crankshaft on the 
mass flow rate of air that goes into cylinders, resulting in decrease in the mass flow rate of air by as much as $10 \%$ which in turn results in unfavorable higher rate of CO exhaust emissions; (VI) the paper has identified the four elements of the pressure of the gas inside the cylinder during the intake stroke-a driving element (intake manifold pressure), and draining elements (vacuum pressure and flow losses and inertial effect of rotating mass); (VII) the developed models are widely valid with explainable mathematical trends so that their developed simplified version can help in better analysing and optimizing the performance of diesel engines.

\section{Limitation and Future Research}

The results of the present research are limited to diesel engines. The validation of these results is limited to the presented data set. Due to the fact that the availability of the field data for validating such research is limited, further validation of the present research results can be provided in future research.

Author Contributions: Conceptualization, S.A.M.E., W.F.F. and H.A.R.; methodology, S.A.M.E., W.F.F. and H.A.R.; analysis, S.A.M.E.; resources, S.A.M.E., W.F.F. and H.A.R.; writing-original draft preparation, S.A.M.E.; supervision and review, W.F.F. and H.A.R.; project administration and funding acquisition, W.F.F. and H.A.R. All authors have read and agreed to the published version of the manuscript.

Funding: This research received funding from the Center for Sustainable Mobility, Virginia Polytechnic Institute and State University, USA. Also, this research received funding from the IIUM, Malaysia, grant \# RMGS 09-10.

Data Availability Statement: The data presented in this study are available on request from the corresponding author.

Acknowledgments: The International Islamic University Malaysia (IIUM) and Virginia Polytechnic Institute and State University (Virginia Tech) are thanked for their support. In addition, the support provided by the University of Coimbra and the Foundation for Science and Technology (FCT) is acknowledged.

Conflicts of Interest: The authors declare no conflict of interest.

\section{References}

1. Elmoselhy, S.A.M.; Rakha, H.A.; Faris, W.F. Experimentally validated analytical modeling of diesel engine power and in-cylinder gas speed dynamics. J. Mech. Sci. Technol. 2016, 30, 4725-4734. [CrossRef]

2. Faris, W.F.; Rakha, H.A.; Kafafy, R.I.; Idres, M.; Elmoselhy, S. Vehicle fuel consumption and emission modelling: An in-depth literature review. Int. J. Veh. Syst. Model. Test. 2011, 6, 318. [CrossRef]

3. Faris, W.F.; Rakha, H.A.; Elmoselhy, S.A. Analytical model of diesel engines exhaust NOx emission rate. Int. J. Veh. Syst. Model. Test. 2014, 9, 264. [CrossRef]

4. Faris, W.F.; Rakha, H.; Elmoselhy, S.A. Impact of Intelligent Transportation Systems on Vehicle Fuel Consumption and Emission Modeling: An Overview. SAE Int. J. Mater. Manuf. 2014, 7, 129-146. [CrossRef]

5. Faris, W.F.; A Rakha, H.; Elmoselhy, S. Validated analytical modeling of diesel engine regulated exhaust CO emission rate. Adv. Mech. Eng. 2016, 8, 1-15. [CrossRef]

6. Wojtkowiak, D.; Talaśka, K.; Wilczyński, D.; Górecki, J.; Wałęsa, K. Determining the Power Consumption of the Automatic Device for Belt Perforation Based on the Dynamic Model. Energies 2021, 14, 317. [CrossRef]

7. Bondar, V.; Aliukov, S.; Malozemov, A.; Das, A. Mathematical Model of Thermodynamic Processes in the Intake Manifold of a Diesel Engine with Fuel and Water Injection. Energies 2020, 13, 4315. [CrossRef]

8. Palazzo, N.; Zigan, L.; Huber, F.J.T.; Will, S. Impact of Oxygenated Additives on Soot Properties During Diesel Combustion. Energies 2020, 14, 147. [CrossRef]

9. Guzzella, L.; Onder, C.H. Introduction to Modeling and Control of Internal Combustion Engine Systems, 2nd ed.; Springer: Heidelberg, Germany, 2010.

10. Acquati, F.; Battarola, L.; Scattolini, R.; Siviero, C. An Intake Manifold Model for Spark Ignition Engines. IFAC Proc. Vol. 1996, 29, 7945-7950. [CrossRef]

11. Ouenou-Gamo, S.; Ouladsine, M.; Rachid, A. Air intake theoretical model and simulation of a turbocharger diesel engine. In Proceedings of the Twenty-Ninth Southeastern Symposium on System Theory, Cookeville, TN, USA, 9-11 March 1997; IEEE: Piscataway, NJ, USA, 2002; p. 332. 
12. Chen, R.-H.; Wang, W.-C.; Chen, Y.-W. Like-drop collisions of biodiesel and emulsion diesel. Eur. J. Mech. B Fluids 2016, 60, 62-69. [CrossRef]

13. Aguilera-Gonza' Lez, A.; Bosche, J.; El hajjaji, A.; Abidi, I. Feedback design air-path control on a diesel engine based on TakagiSugeno fuzzy descriptor systems. In Proceedings of the Mediterranean Conference on Control \& Automation, Platanias-Chania, Crete, Greece, 25-28 June 2013; IEEE: Piscataway, NJ, USA, 2013.

14. Mehta, H.B.; Bharti, O.S. Performance analysis of an irreversible Otto cycle using finite time thermodynamics. In Proceedings of the World Congress on Engineering, London, UK, 29 June-1 July 2009; WCE: London, UK, 2009; Volume II.

15. Kumhar, G.K.; Singh, S.K.; Babhale, T.; Machinery, F.E.A. Design and Analysis of Four Cylinder Diesel Engine Balancer Shaft. Int. J. Eng. Res. 2016, 5. [CrossRef]

16. Chaubey, A.; Tiwari, A.C. Design and CFD analysis of the intake manifold for the Suzuki G13bb engine. Int. J. Res. Appl. Sci. Eng. Technol. (IJRASET) 2017, 5, 1258-1276.

17. Vojtíšek, M.; Kotek, M. Estimation of Engine Intake Air Mass Flow using a generic Speed-Density method. J. Middle Eur. Constr. Des. Cars 2014, 12, 7-15. [CrossRef]

18. Rakha, H.A.; Ahn, K.; Faris, W.F.; Moran, K.S. Simple Vehicle Powertrain Model for Modeling Intelligent Vehicle Applications. IEEE Trans. Intell. Transp. Syst. 2012, 13, 770-780. [CrossRef]

19. Faris, W.F.; Rakha, H.A.; Elmoselhy, S.A. Supercharged diesel powertrain intake manifold analytical model. Int. J. Veh. Syst. Model. Test. 2014, 9. [CrossRef]

20. Alhinti, I.; Samhouri, M.; Al-Ghandoor, A.; Sakhrieh, A. The effect of boost pressure on the performance characteristics of a diesel engine: A neuro-fuzzy approach. Appl. Energy 2009, 86, 113-121. [CrossRef]

21. Ma, X.; You, X.; Wen, B. Multi-body dynamics simulation on flexible crankshaft system. In Proceedings of the 12th IFToMM World Congress, Besançon, France, 18-21 June 2007.

22. Kaya, T.; Temiz, V.; Parlar, Z. Optimum connecting rod design for diesel engines. Trans. Motauto World 2016, 1, 96-100.

23. Jung, M.; Glover, K. Control-oriented linear parameter-varying modelling of a turbocharged diesel engine. In Proceedings of the 2000 IEEE International Conference on Control Applications, Taipei, Taiwan, 2-4 September 2004; Conference Proceedings (Cat. No.00CH37162). IEEE: Piscataway, NJ, USA, 2004.

24. Obert, E.F. Internal Combustion Engines and Air Pollution; Harper \& Row Publishers, Inc.: New York, NY, USA, 1973.

25. Taylor, C.F.; Glaister, E. The Internal Combustion Engine in Theory and Practice. J. Appl. Mech. 1961, 28, 316-317. [CrossRef]

26. Mamat, R.; Abdullah, N.R.; Xu, H.; Wyszynski, M.L.; Tsolakis, A. Effect of air intake pressure drop on performance and emissions of a diesel engine operating with biodiesel and ultra low sulphur diesel (ULSD). Renew. Energy Power Qual. J. 2009, 1, 787-794. [CrossRef]

27. Rama, D.D.; Durgaiah, D.R. Fluid Mechanics and Machinery; New Age International: New Delhi, India, 2007 ; p. 784.

28. $\mathrm{Xu}, \mathrm{J}$. Flow analysis of engine intake manifold based on computational fluid dynamics. J. Phys. Conf. Ser. 2017, 916, 012043. [CrossRef]

29. Louvigny, Y.; Vanoverschelde, N.; Janssen, G.; Breuer, E.; Duysinx, P. Dynamic analysis and preliminary design of twin cylinder engines for clean propulsion systems. In Proceedings of the Multibody Dynamics 2009 ECCOMAS Thematic Conference, Warsaw, Poland, 29 June-2 July 2009; European Community on Computational Methods in Applied Sciences: Barcelona, Spain, 2009.

30. Green, D.W.; Perry, R.H. Perry's Chemical Engineers' Handbook, 6th ed.; McGraw-Hill: New York, NY, USA, $1984 ;$ pp. 3-162.

31. Cengel, Y.A.; Cimbala, J.M. Fluid Mechanics; McGraw Hill: New York, NY, USA, 2006.

32. Kudela, H. Lectures in Fluid Mechanics. Department of Numerical Flow Modeling, Politechnika Wrocławska. 2018. Available online: http:/ / fluid.itcmp.pwr.wroc.pl/ \{\}znmp/dydaktyka/fundam_FM/Lecture11_12.pdf (accessed on 19 December 2018).

33. Faris, W.F.; Rakha, H.; Elmoselhy, S.A. Analytical Modelling of Diesel Powertrain Fuel System and Consumption Rate. SAE Int. J. Mater. Manuf. 2015, 8, 139-152. [CrossRef]

34. United States Environmental Protection Agency EPA. Process for Conducting Probabilistic Risk Assessment; Appendix A. RAGS; Environmental Protection Agency EPA: Washington, DC, USA, 2001; Volume 3, Part A.

35. Edelbrock Pro-Flo XT EFI LS1 Chevy Intake Manifold Systems 2021. Available online: https://www.edelbrock.com/pro-flo-xtefi-intake-manifold-71373.html (accessed on 18 January 2021).

36. Eaton M90 Supercharger 2021. Available online: http://www.eaton.com/Eaton/ProductsServices/Vehicle/Superchargers/ diesel-supercharger/index.htm\#tabs-1 (accessed on 19 January 2021).

37. Mitsubishi Motors. Mitsubishi Motors Develops New 3.2-liter Direct Injection Diesel. Available online: https:/ / www.mitsubishimotors.com/en/corporate/pressrelease/corporate/detail724.html (accessed on 18 January 2021).

38. Nikkar, S. Estimation of in-Cylinder Trapped Gas Mass and Composition. Master's Thesis, Linköping University, Linköping, Sweden, 2017.

39. Lückert, P.; Schommers, J.; Werner, P.; Roth, T. The new four-cylinder diesel engine for the Mercedes-Benz B-Class. MTZ Worldw. eMagazine 2011, 72, 18-25. [CrossRef]

40. Milašinović, A.; Milovanovic, Z.; Knežević, D.; Mujanić, I. Determination of Differential Equations of Motion and Parameters of an Elastic Internal Combustion Engine Crankshaft. Trans. FAMENA 2016, 40, 83-95. [CrossRef]

41. Bosch Automotive Handbook, 9th ed.; Wiley: Hoboken, NJ, USA, 2014.

42. Kimura, J.; Yamashita, T. Diesel Engine Crankshaft Rotational Speed Fluctuation Analysis. Des. Appl. Perform. Emiss. Mod. Intern. Combust. Engine Syst. Compon. 2003, 263-269. [CrossRef] 
43. De Farias, M.S.; Schlosser, J.F.; Martini, A.T.; Dos Santos, G.O.; Estrada, J.S. Air and fuel supercharge in the performance of a diesel cycle engine. Ciência Rural 2017, 47. [CrossRef]

44. Sulaiman, S.A.; Murad, S.H.M.; Ibrahim, I.; Karim, Z.A.A. Study of Flow in Air-Intake System for A Single-Cylinder Go-Kart Engine. Int. J. Automot. Mech. Eng. 2010, 1, 91-104. [CrossRef]

45. Pesic, R.; Davinic, A.; Petkovic, S.; Taranovic, D.; Miloradovic, D. Aspects of volumetric efficiency measurement for reciprocating engines. Therm. Sci. 2013, 17, 35-48. [CrossRef]

46. Haapakoski, J. Medium-Speed Four-Stroke Diesel Engine Cylinder Pressure Effect on Component Dimensioning. Master's Thesis, University of Oulu, Oulu, Finland, 2016.

47. Idris, A.; Bakar, R.A.; Ismail, A.R. Engine cylinder fluid characteristics of diesel engine converted to CNG engine. Eur. J. Sci. Res. 2009, 26, 443-452.

48. Keller, G. Statistics for Management and Economics, 9th ed.; South Western, Cengage Learning: Mason, OH, USA, 2012.

49. Yongkang Guihou Industry and Trade Co., Ltd. 150cc 4-Stroke Single Cylinder Go Kart ATV Jeep 2016. Available online: https:/ / emtosales.en.made-in-china.com/product/AKwJSHWOXmru/China-150cc-200-Cc-4-Stroke-Single-CylinderAir-Cooled-Go-Kart-ATV-Factory-Price-Jeep-2016.html (accessed on 19 January 2021).

50. Ibrahim, A.; Dunn, P. Effects of temporal flow acceleration on the detachment of microparticles from surfaces. J. Aerosol Sci. 2006, 37, 1258-1266. [CrossRef]

51. Holmgren, A. Mean Value Modelling of the Intake Manifold Temperature. Master's Thesis, Linkopings Universitet, Linköping, Sweden, 2005.

52. Wortmann, S.; Vilhena, M.T.; Moreira, D.M.; Buske, D. A new analytical approach to simulate the contaminant dispersion in the PBL. Atmos. Environ. 2005, 39, 2171-2178. [CrossRef]

53. Bos, M. Validation Gt-Power Model Cyclops Heavy Duty Diesel Engine. Master's Thesis, The Technical University of Eindhoven, Eindhoven, The Netherlands, 2007.

54. Reşitoğlu, İ.A.; Altinişik, K.; Keskin, A. The pollutant emissions from diesel-engine vehicles and exhaust aftertreatment systems. Clean Technol. Environ. Policy 2015, 17, 15-27. [CrossRef]

55. Khajepour, A.; Fallah, S.; Goodarzi, A. Electric and Hybrid Vehicles-Technologies, Modeling and Control: A Mechatronic Approach; Wiley-Blackwell: Hoboken, NJ, USA, 2014; ISBN 978-1-118-40310-5.

56. Lapuerta, M.; Hernández, J.J.; Rodríguez-Fernández, J.; Barba, J.; Ramos, A.; Fernández-Rodríguez, D. Emission benefits from the use of n-butanol blends in a Euro 6 diesel engine. Int. J. Engine Res. 2018, 19, 1099-1112. [CrossRef]

57. Malkawi, G.; Mashayek, F.; Yarin, A.L. Breakup mechanisms of electrostatic atomization of corn oil and diesel fuel. J. Appl. Phys. 2010, 108, 064910. [CrossRef]

58. Elmoselhy, S.A.M. Hybrid Organic/Inorganic Nano-I-Beam for Structural Nano-mechanics. Sci. Rep. 2019, 9, 1-13. [CrossRef]

59. Serrano, J.R.; Arnau, F.; Martín, J.; Auñón, Á. Development of a Variable Valve Actuation Control to Improve Diesel Oxidation Catalyst Efficiency and Emissions in a Light Duty Diesel Engine. Energies 2020, 13, 4561. [CrossRef]

60. Heywood, J. Internal Combustion Engine Fundamentals; McGraw Hill: New York, NY, USA, 1988.

61. Elmoselhy, S.; Faris, W.F.; Rakha, H.A. Experimentally validated analytical modeling of diesel exhaust HC emission rate. J. Mech. Sci. Technol. 2014, 28, 4139-4149. [CrossRef] 